\title{
Young Children of Immigrants
}

\section{The Leading Edge of America's Future}

Brief No. 3

THE URBAN INSTITUTE

\section{Karina Fortuny, Donald J. Hernandez, and Ajay Chaudry}

$\mathbf{T}$

his brief highlights the life circumstances of young children age 0 to 8 growing up in immigrant families. ${ }^{1}$

\section{Immigration Trends}

The number of young children of immigrants has doubled since 1990; this increase accounts for the entire growth in the U.S. population of young children since 1990

- Currently, 8.7 million U.S. children age 0 to 8 have at least one foreign-born parent, a doubling from 4.3 million in $1990 .^{2}$ By contrast, the number of children with native-born parents has declined slightly from 27.8 million in 1990 to 27.3 million in 2008 . Thus, children of immigrants accounted for the entire growth in the

Figure 1. Growth in Number of Children of Immigrants and Children of Natives Age 0-8, 1990 to 2008 (thousands)

Children of immigrants

Children of natives

All children

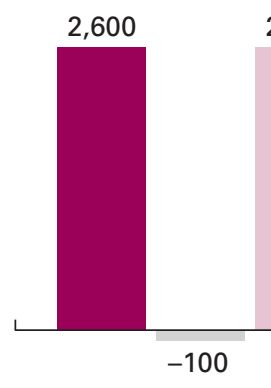

$1990-2000$

\section{2,600}

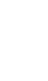

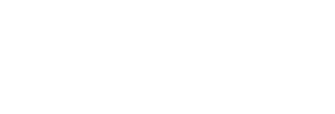

4,400

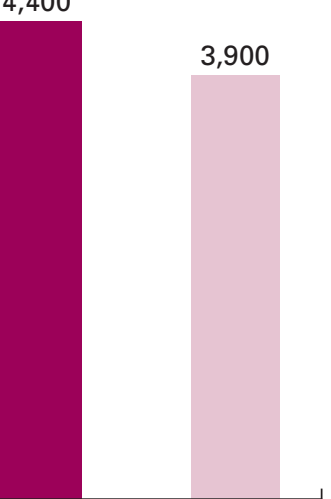

1,700

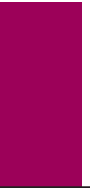

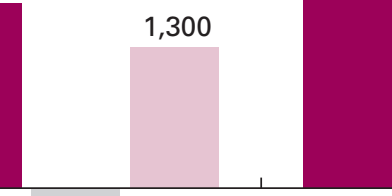

$-500$

2000-2008 number of young children in the United States between 1990 and 2008 (figure 1).

- Nearly one in four children (24 percent) younger than age 8 have immigrant parents. The share has steadily increased over time, rising from 13 percent in 1990 to 20 percent in 2000 and to 24 percent in 2008.

- Young children are more likely to have immigrant parents than older children. In 2008, 25 percent of children age $0-2$ have immigrant parents; the share is 24 percent for children age $3-5$ and 23 percent for those age 6-8.

\section{Young children of immigrants have diverse origins}

- Forty-three percent of young children of immigrants age $0-8$ (more than two of every five) have Mexican parents (figure 2). Looking beyond Mexican origin, however, immigrant origins are very diverse, with no more than 10 percent of children having parents from any of the other 10 broad regions of the world. Combining three regions, 20 percent have origins in the countries of Central America (8 percent), the Caribbean (7 percent), or South America (6 percent). Another 22 percent of children have parents born in Asia or the Middle East: East Asia and Pacific (or "East Asia," 9 percent), South Central Asia (5 percent), Southeast Asia ( 4 percent), and the Middle East (3 percent). The remaining 15 percent of children have parents born in Africa, Central and Eastern Europe (or "Central Europe"), and Western Europe, Canada, and Australia (or "Western Europe").

- The shares of preschool-age children of African or Central American origin are likely to increase in the near 
Figure 2. Children of Immigrants Age 0-8 by Parents' Region of Origin, 2007-08

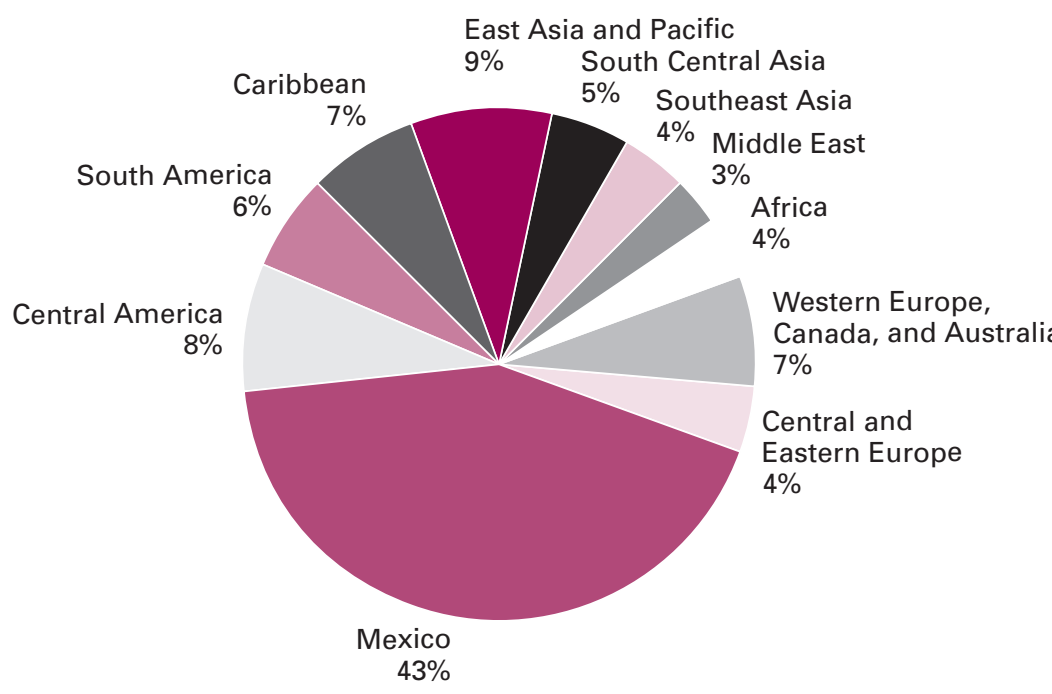

8.7 million children of immigrants

Source: Urban Institute tabulations from the IPUMS datasets drawn from the 2007 and 2008 American Community Surveys.

future. The fastest growing populations of children age 0 to 2 are those whose parents emigrated from Africa or Central America; compared with children age 6-8, the number of children age $0-2$ is 32 percent larger for those with African parents and 28 percent larger for those with Central American parents.

Young children of immigrants are still bighly concentrated, but they and their families have been dispersing to nontraditional immigrant states

- Of all children under the age of 8 with immigrant parents, more than a quarter (26 percent) live in California (figure 3 ). This is twice the state's share of all children in the United States (13 percent) and three times its share of children with native-born parents (8 percent). Half of all young children in California are children of immigrants.

- Young children of immigrants are also strongly concentrated in several other traditional immigrant destination states: Texas (13 percent of all children of immigrants), New York (8 percent), Florida (7 percent), Illinois (5 percent), and New Jersey (4 percent). ${ }^{3}$ Together, these "big six" immigrant destination states account for 63 percent of all children of immigrants in the United States.

- While the large, traditional immigrant destination states continue to have a majority share of all children of immigrants in the United States, immigrants have been dispersing across many other states in recent decades. Many states have much higher growth rates in their share of young children of immigrants than the traditional immigrant destination states. Seventy-three percent of young children of immigrants lived in the big six states in 1990, compared with 63 percent in 2008. The proportion of young children of immigrants living in the 22 new-growth states increased from 12 to 23 percent between 1990 and 2008 (see appendix table 1).

- Across the United States, young children of immigrants account for more than 30 percent of children in seven states and 20-30 percent of children in 12 states. Children of immigrants account for between 10 and 20 percent of children in 18 states. Their share is lower in the remaining 14 states (less than 10 percent of children, as shown in figure 4).

\section{Impact on Schools}

\section{Children of immigrants have lower rates of preschool enrollment at younger ages}

- Children of immigrants have lower rates of preschool enrollment at ages 3 and 4 than children of natives: 31 percent of 3 -year-old children of immigrants are enrolled in preschool versus 37 percent of children of natives (figure 5, page 4). The enrollment gap narrows somewhat for children age 4 (58 versus 62 percent), and closes at age 5 when most children are in kindergarten ( 87 versus 86 percent).

- A few immigrant origins account for most of the enrollment gap between children of immigrants and natives at age 3: Mexico (19 percent enrollment at age 3), Central America (21 percent), and Southeast Asia (31 percent). All other immigrant-origin groups have enrollment rates that exceed the 37 percent rate for 3-year-old children of natives: Western Europe is 53 percent, Asia (excluding Southeast Asia) is 42-46 percent, the Caribbean is 44 percent, Africa 
Figure 3. Distribution across States of Children of Immigrants Age 0-8, 2007-08

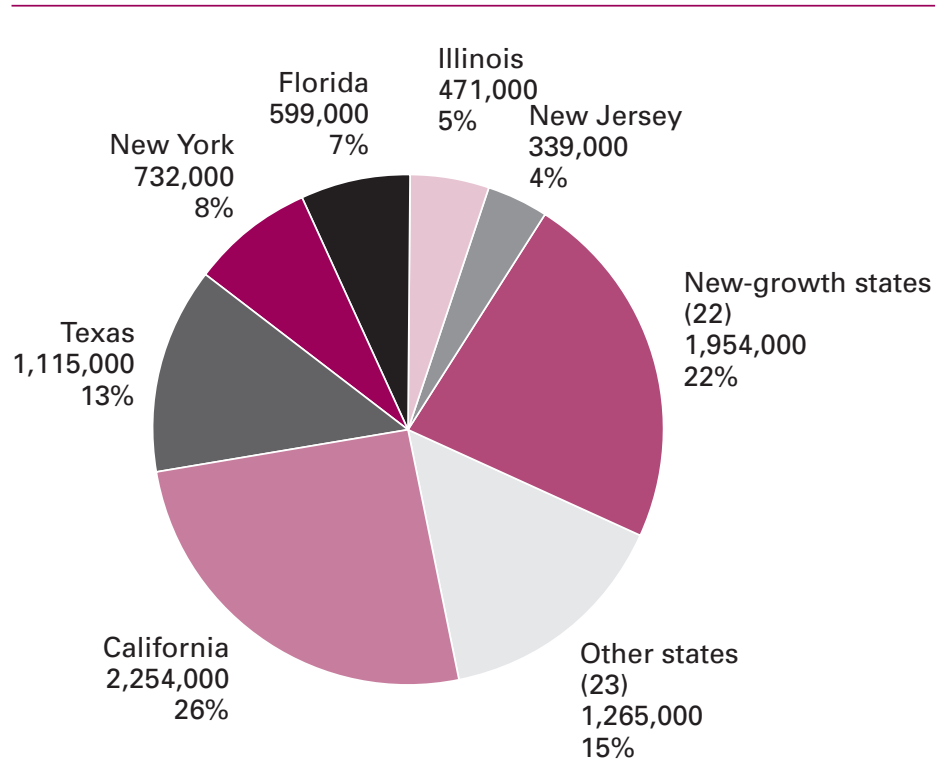

8.7 million children of immigrants

Source: Urban Institute tabulations from the IPUMS datasets drawn from the 2007 and 2008 American Community Surveys.

Note: The new-growth states are Alabama, Arkansas, Arizona, Colorado, Delaware, Georgia, Iowa, Idaho, Indiana, Kansas, Kentucky, Minnesota, Mississippi, North Carolina, Nebraska, Nevada, Oklahoma, Oregon, South Carolina, Tennessee, Utah, and Washington.

Figure 4. Share of Children Age 0-8 with Immigrant Parents by State, 2007-08

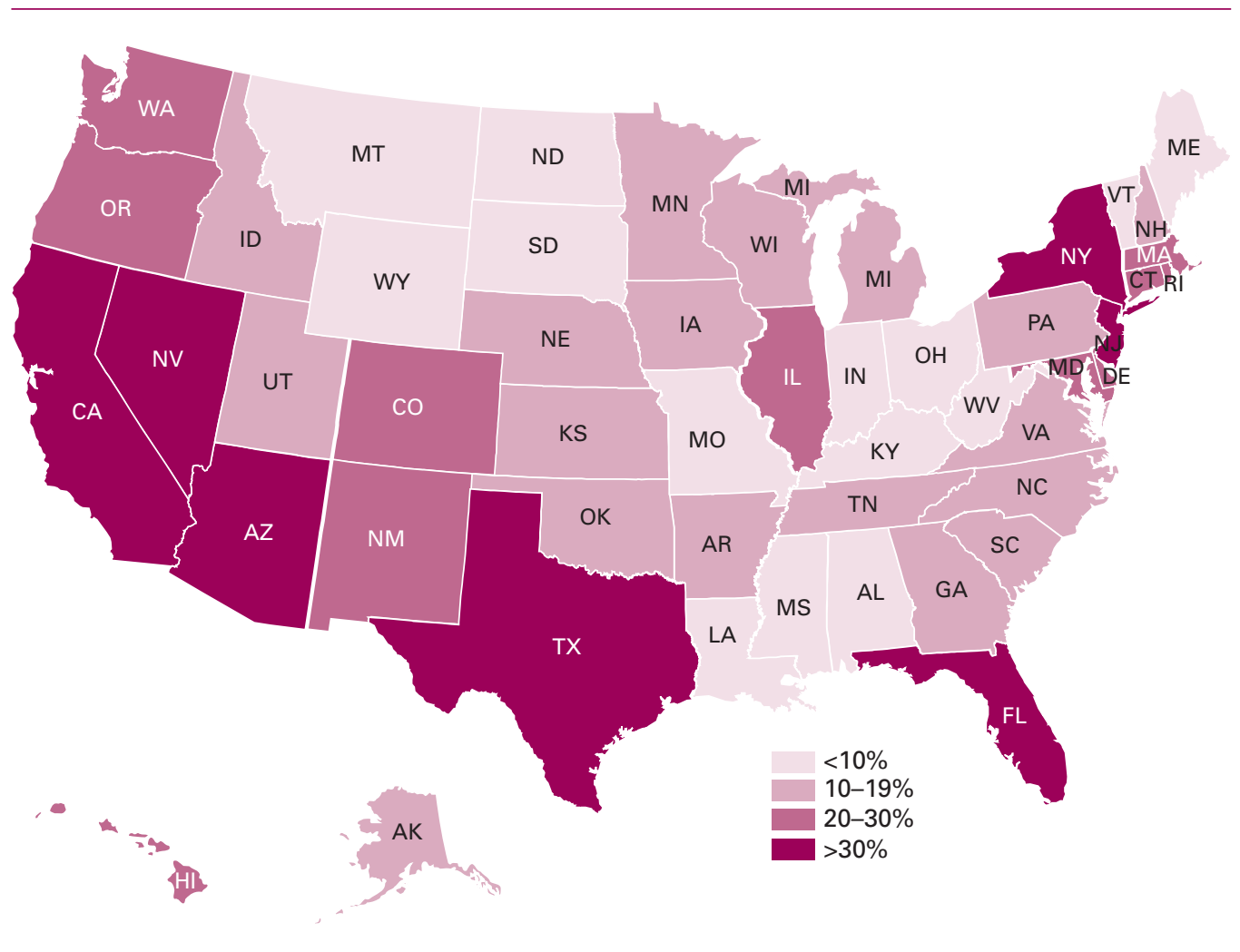

Source: Urban Institute tabulations from the IPUMS datasets drawn from the 2007 and 2008 American Community Surveys. 


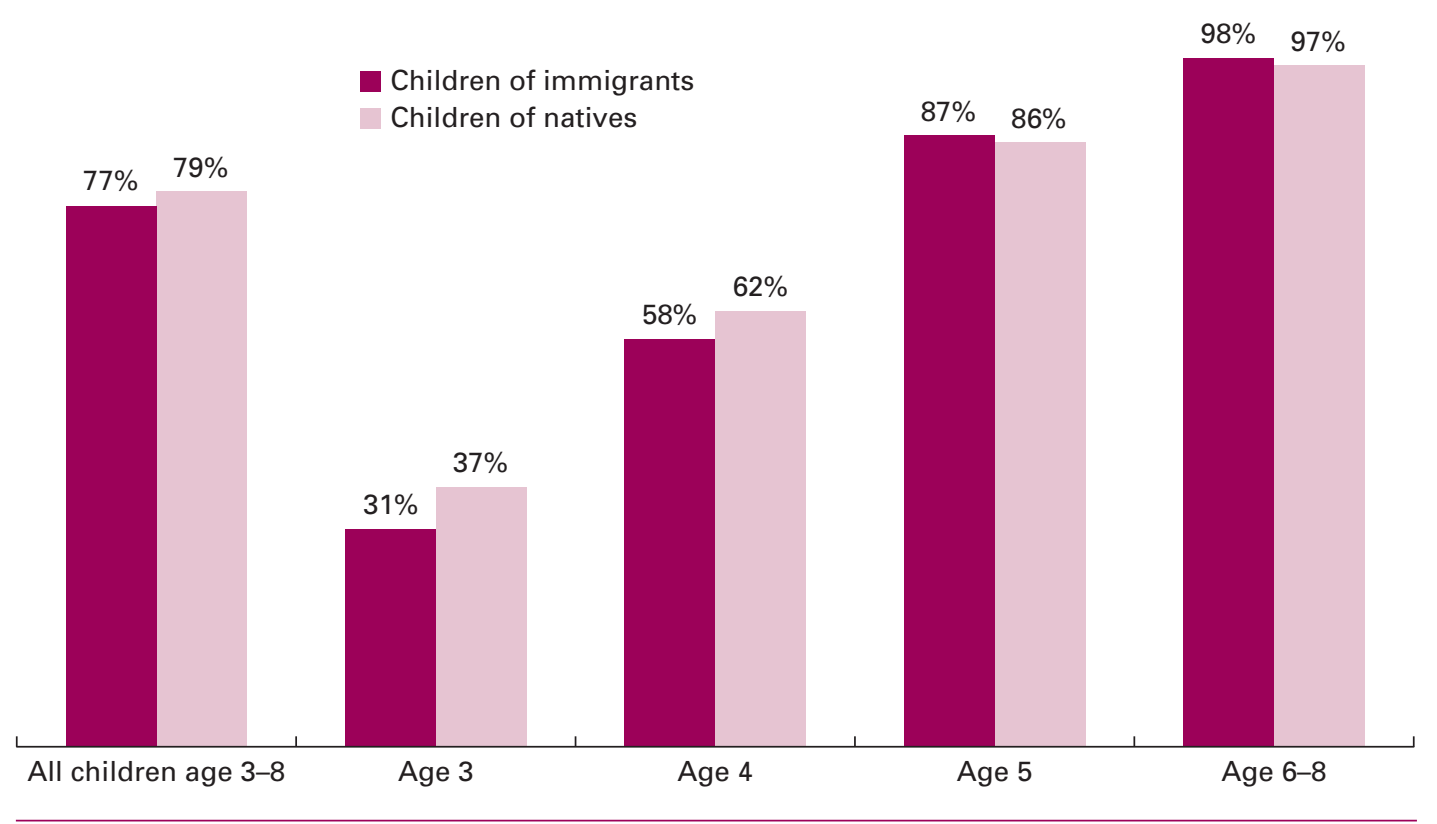

Source: Urban Institute tabulations from the IPUMS datasets drawn from the 2007 and 2008 American Community Surveys.

is 42 percent, and South America is 41 percent. Underenrollment among children of some origin groups can be accounted for by limited socioeconomic resources and lack of availability of appropriate programs in the neighborhoods of these immigrants (Hernandez, Denton, and Macartney forthcoming).
A quarter of preschool-age children are English language learners, and more than half have ELL parents

- Twenty-seven percent of children of immigrants age 5-8 are English language learners (ELLs). ${ }^{4}$ The share is highest for 5 -year-olds, at 37 percent; it declines to 20 percent for 8 -year-olds (figure 6). The share of bilingual

Figure 6. Shares of Children of Immigrants Age 5-8 That Are Bilingual and English Language Learners, 2007-08

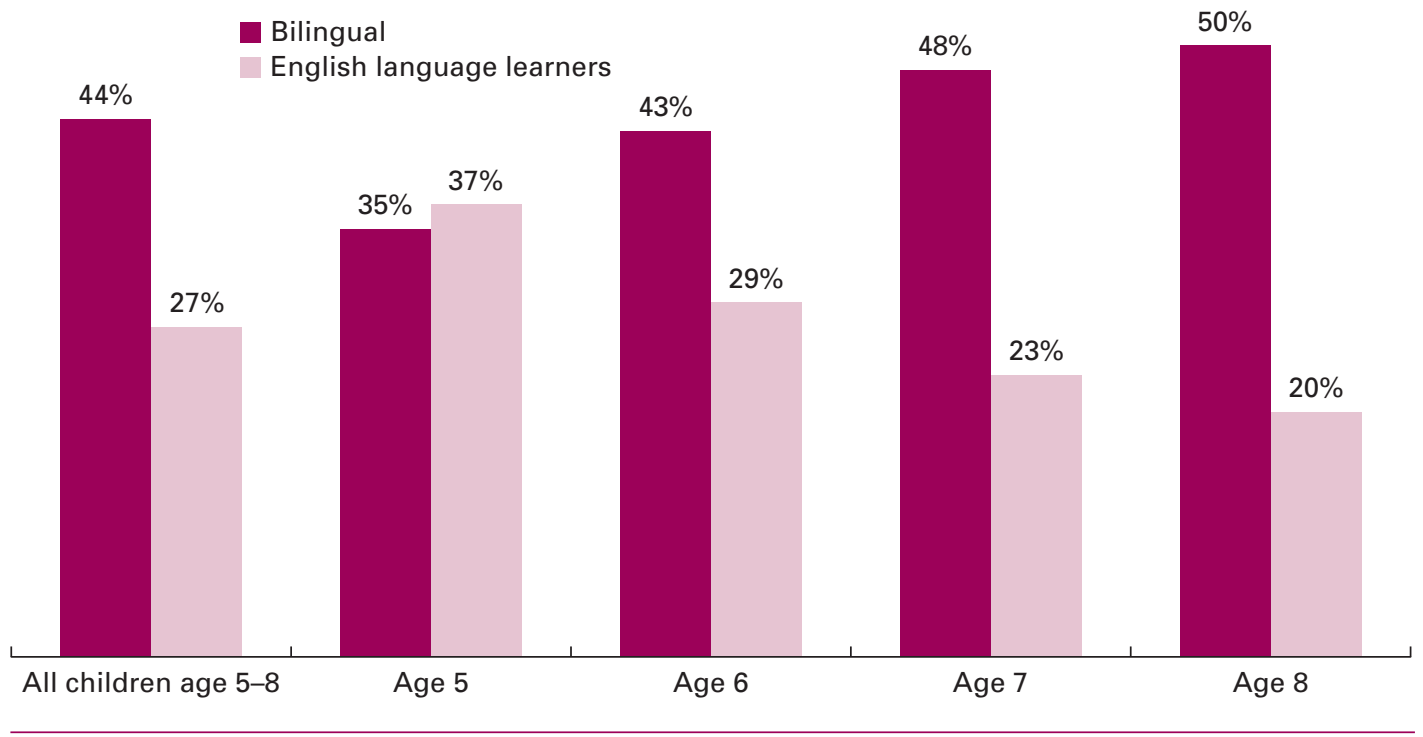

Source: Urban Institute tabulations from the IPUMS datasets drawn from the 2007 and 2008 American Community Surveys. 
children increases with age: by age 8 , half of children of immigrants speak English very well and speak another language at home.

- More than half (60 percent) of young children of immigrants have at least one ELL parent (figure 7). A large majority of children of Mexican origin (81 percent) and Central American origin (71 percent) have ELL parents. Forty percent of children with Caribbean parents have ELL parents, but the rate is much higher for those with Dominican parents (65 percent). Among non-Spanish-speaking countries of origin, children of Southeast Asian origin are the most likely to have ELL parents, at 62 percent. Countries in this region with high ELL rates include Burma/Myanmar at 77 percent and Vietnam at 66 percent. Other nonSpanish-speaking countries with aboveaverage ELL rates include Somalia (78 percent), Uzbekistan (70 percent), Bangladesh (67 percent), and Albania, Sudan, and China (each at 65 percent).

- A third (34 percent) of young children of immigrants live in linguistically isolated households where no person age 14 or older is English proficient. The rates are relatively high for all origin groups except children of Western European origin (at 3 percent). The linguistically isolated shares are highest for children of Mexican origin (48 percent) and Central American origin (41 percent), followed by children of Southeast Asian origin (33 percent). Relatively fewer children of South Central Asian (15 percent) and Middle Eastern origins (16 percent) are linguistically isolated.

\section{Parental and Family Characteristics}

Most young children of immigrants are U.S. citizens, but half live in families with noncitizen parents

- The vast majority (93 percent) of young children of immigrants are U.S. citizens. Virtually all young children of immigrants that are U.S. citizens are citizens by birth (99 percent). The citizen share is highest for the youngest children, because they are more likely to have been born in the United States: 97 percent of children age $0-2$ are citizens, compared with 89 percent of children age 6-8.
Figure 7. Share of Children of Immigrants Age 0-8 with English-Language-Learner Parents, by Parents' Region of Origin, 2007-08

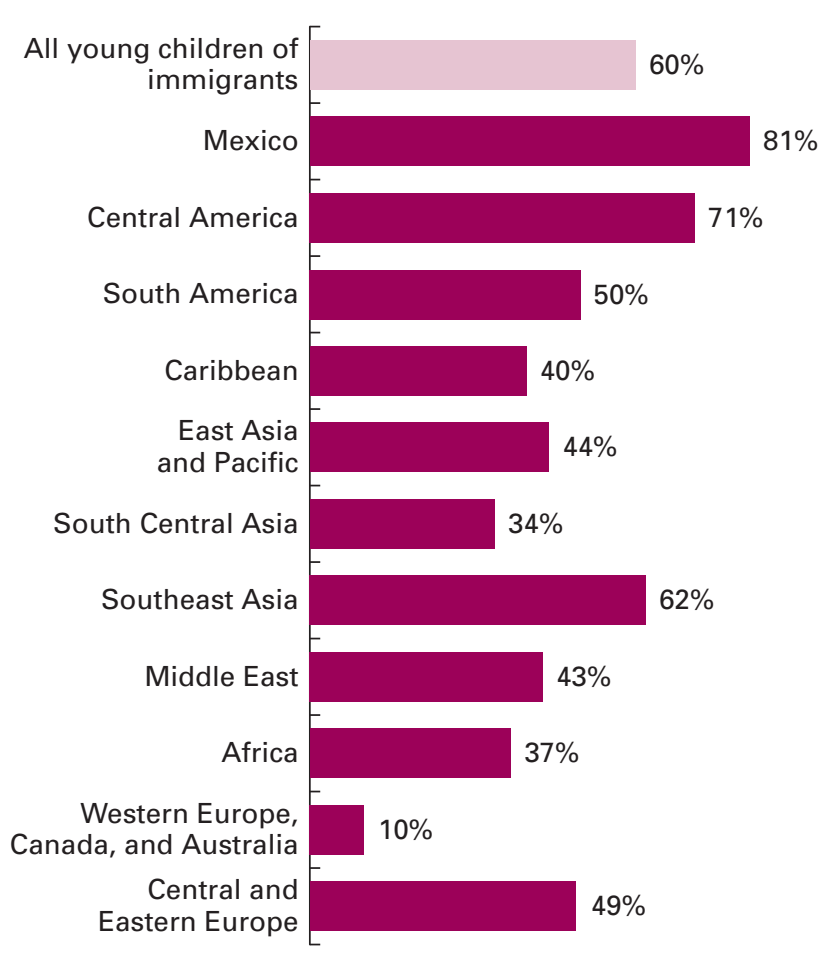

Source: Urban Institute tabulations from the IPUMS datasets drawn from the 2007 and 2008 American Community Surveys.

- About half (53 percent) of young children of immigrants are in families where at least one parent is a U.S. citizen. The citizen share, however, varies by immigrant origin. Less than half of children of Mexican origin (36 percent) and Central American origin (43 percent) have citizen parents. However, more than three-quarters of children of Southeast Asian (83 percent), Middle Eastern (82 percent), and Western European origin (81 percent) have citizen parents.

- While most young children of immigrants are citizens, a large share ( 43 percent) lives in mixed-status families where the children are citizens and the parents are noncitizens. ${ }^{5}$ More than half of children of Mexican origin (61 percent) and Central American origin (55 percent) live in mixed-status families (figure 8). Parents born in these countries are more likely to be unauthorized immigrants ineligible for naturalization. Slightly more than one-third of citizen children with parents 
Figure 8. Share of Children of Immigrants Age 0-8 in Mixed-Status Families, by Parents' Region of Origin, 2007-08

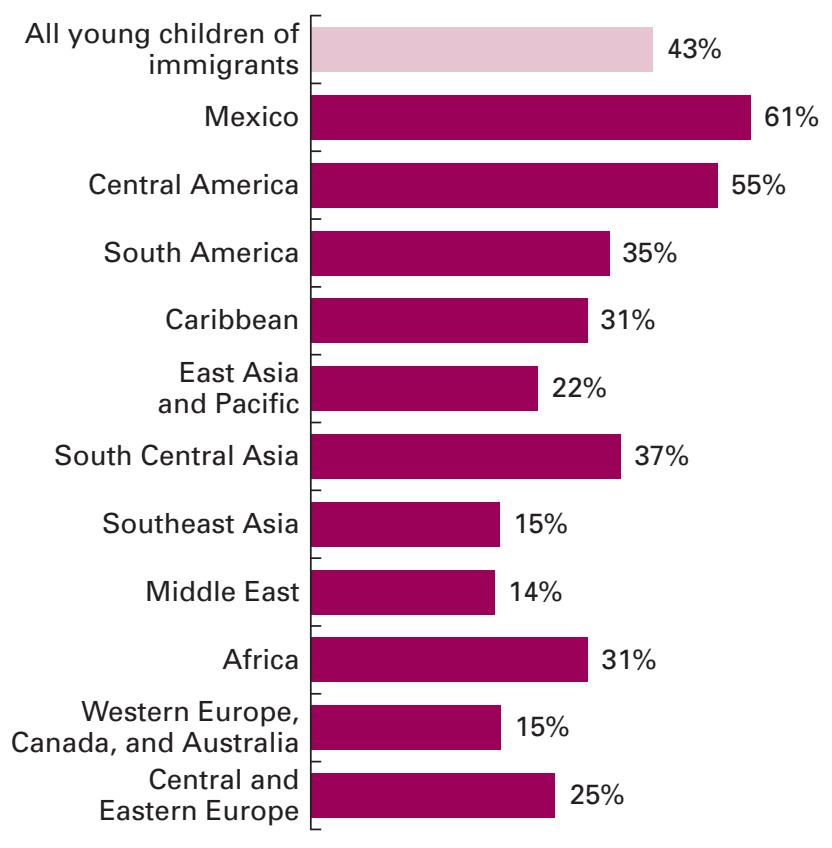

Source: Urban Institute tabulations from the IPUMS datasets drawn from the 2007 and 2008 American Community Surveys.

Note: In mixed-status families, at least one child is a U.S. citizen and neither parent is a citizen. Noncitizens include legal immigrants, such as legal permanent residents and refugees, and unauthorized immigrants. born in South America (35 percent) and South Central Asia (37 percent) also live with noncitizen parents. Children with parents from Southeast Asia have a lower incidence of living in mixed-status families (15 percent). Most immigrants from Southeast Asian countries, such as Laos and Cambodia, are refugees who are eligible to obtain U.S. citizenship within a few years of U.S. residency; this helps explain the lower incidence of mixed-status families.

\section{Parental education varies substantially across immigrant origin}

- While virtually all young children of natives have parents with at least 9th grade educations, 12 percent of children of immigrants have parents who have not completed 9th grade (figure 9). ${ }^{6}$ An additional 13 percent of young children of immigrants have parents with some high school education, but not a high school degree or the equivalent. Overall, 25 percent of children of immigrants have parents with less than high school degrees, compared with 8 percent of children of natives. At the higher end of the education distribution, young children of immigrants are somewhat less

Figure 9. Parental Education of Children Age 0-8 by Parents' Nativity, 2007-08

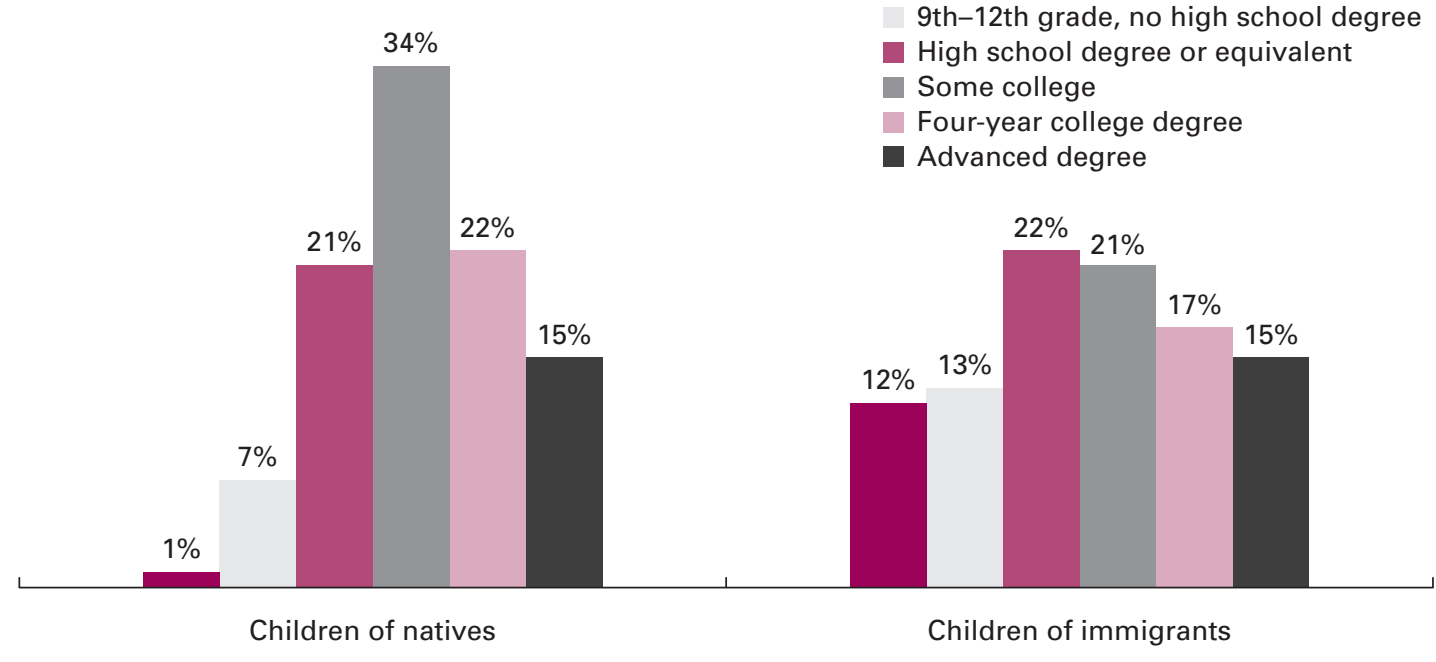

Source: Urban Institute tabulations from the IPUMS datasets drawn from the 2007 and 2008 American Community Surveys. Note: Parental education is the highest attainment of the mother and/or father. 
likely than children of natives to have parents with four-year college degrees (17 versus 22 percent). The advanced-degree share is the same for children of immigrants and natives, 15 percent.

- Parental education varies widely by region of origin. Forty-four percent of young children of Mexican origin and 37 percent of children of Central American origin have parents who have not completed high school (figure 10). About a third of children with parents from Guatemala (31 percent) have not completed a 9th grade education; the shares are also high for children with parents from Honduras (24 percent) and Mexico (21 percent). Children of Mexican and Central American origin account for 88 percent of children whose parents have not completed high school. Two additional origin groups with comparatively high proportions of children whose parents do not have high school educa- tions are the Caribbean (12 percent), particularly the Dominican Republic (23 percent), and Southeast Asia (14 percent), especially Burma/Myanmar (30 percent) and Laos (19 percent). The share is also especially high for children with parents from Somalia: 36 percent have parents without 9th grade educations, and 5 percent have parents who completed 9th grade or higher but have not obtained high school degrees.

- Young children of Caribbean origin are the most likely to have parents who have high school degrees but not college educations (58 percent). At the higher end of the spectrum, the most children of South Central Asian origin (84 percent), East Asian origin (70 percent), and Western European origin (68 percent) have parents with four-year college degrees or more education. The college-educated share is also high (between

Figure 10. Parental Education of Children of Immigrants Age 0-8, by Parents' Region of Origin, 2007-08

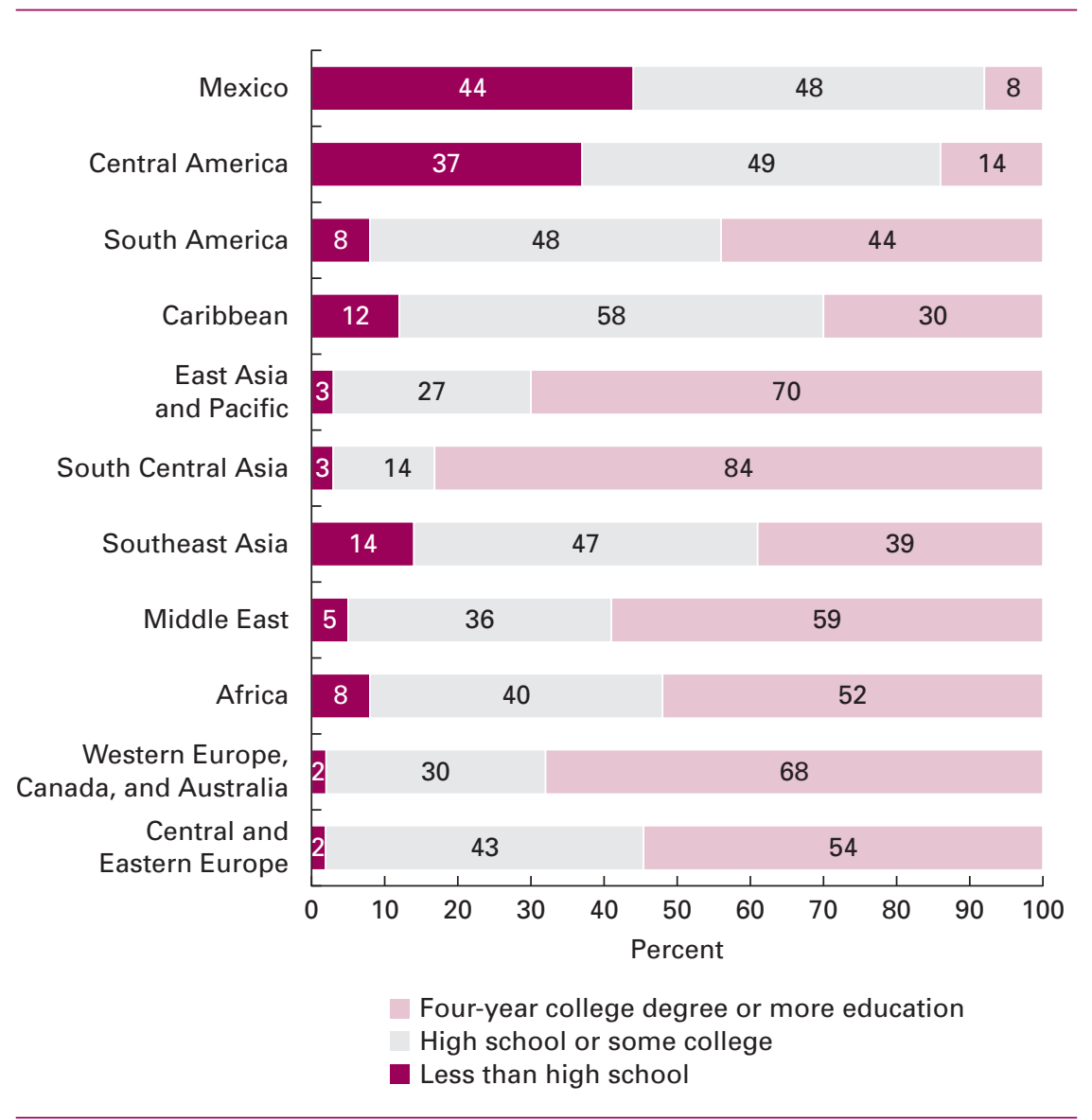

Source: Urban Institute tabulations from the IPUMS datasets drawn from the 2007 and 2008 American Community Surveys. 
50 and 60 percent) for children of Middle

Eastern, African, and Eastern European origins.

Young children of immigrants are disproportionately poor or low income

- Young children of immigrants account for 29 percent of poor children and 30 percent of low-income children. ${ }^{7}$ About half (51 percent) of children of immigrants live in low-income families compared with 38 percent of children of natives. The poverty rate for children of immigrants is also higher than the rate for children of natives (22 versus 17 percent).

- The low-income shares vary by immigrant origin, reflecting differences in education, language skills, and citizenship. More than half of young children of Mexican origin (71 percent) and Central American origin (59 percent) live in low-income families (figure 11). Almost half of children with Caribbean (48 percent) and African parents (46 percent) also live in low-income families. These proportions are especially high for Somalia (86 percent), Yemen (83 percent), and the Dominican Republic (61 percent). The low-income shares are also relatively high for young children with parents from some Southeast Asian countries: Burma/Myanmar (52 percent), Laos (46 percent), and Cambodia (45 percent). Children of Western European origin (17 percent) and Central European origin (30 percent) are the least likely to live in low-income families.

The incidence of two-parent families is higher for young children of immigrants

- Young children of immigrants are more likely than children of natives to live in two-parent families: 84 versus 71 percent. More than 90 percent of children of Asian and European origin live in two-parent families (figure 12). Children of Caribbean origin are the least likely to live in two-parent families, at 65 percent.

Figure 11. Share of Children of Immigrants Age 0-8 in Poverty and Near Poverty by Parents' Region of Origin, 2007-08

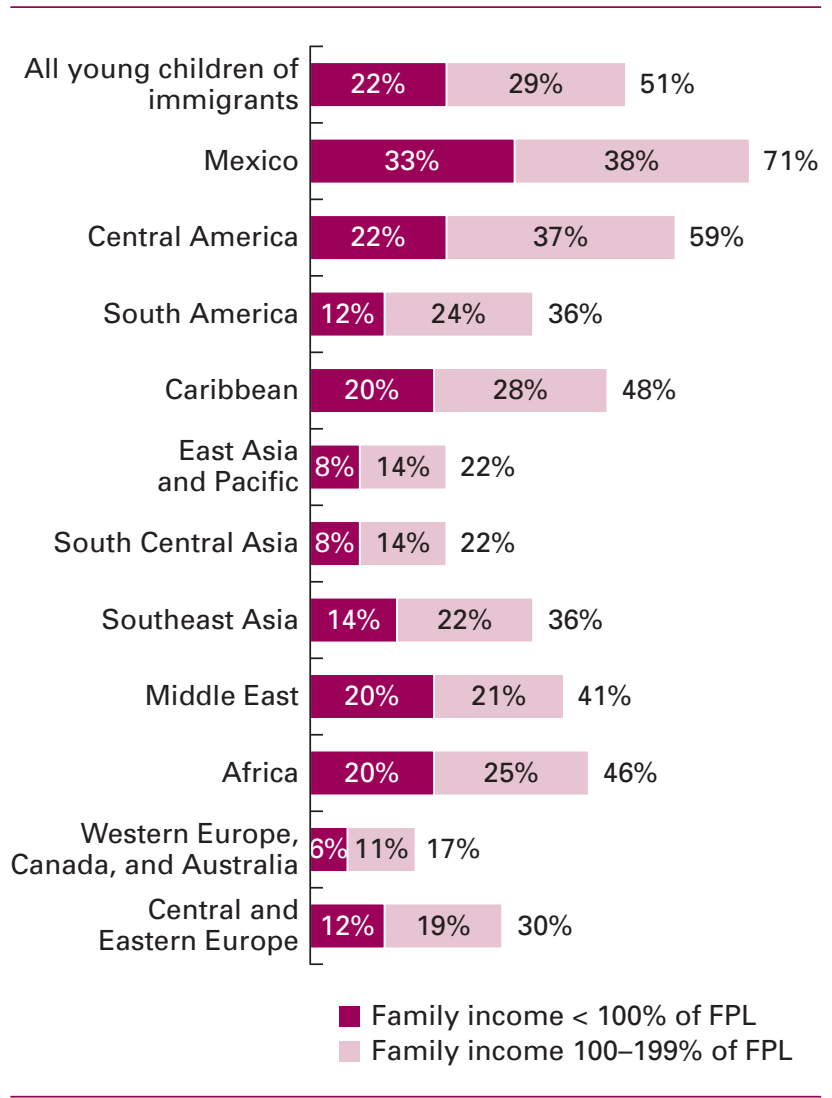

Source: Urban Institute tabulations from the IPUMS datasets drawn from the 2007 and 2008 American Community Surveys.
Figure 12. Share of Children of Immigrants Age 0-8 in Two-Parent Families, by Parents' Region of Origin, 2007-08

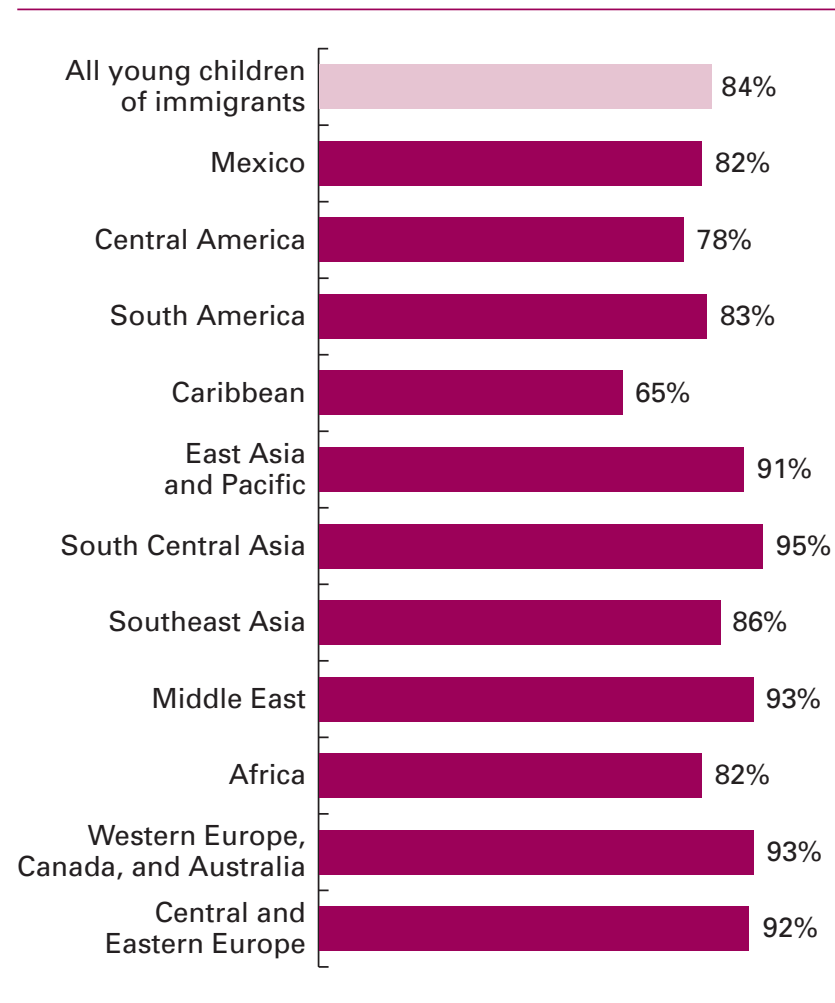

Source: Urban Institute tabulations from the IPUMS datasets drawn from the 2007 and 2008 American Community Surveys. 


\section{Notes}

1. Many results presented here extend to 2008 earlier analyses by Hernandez and colleagues of data from Census 2000 and the American Community Survey. For a more detailed assessment of the circumstances of young English language learners, see Hernandez, Macartney, and Denton (2010); for an extensive policy report on children in immigrant families, see Hernandez, Denton, and Macartney (2008). Go to http://www.albany.edu/csda/children for additional results presenting 140 indicators covering additional topics for children by detailed country-of-origin and race-ethnic group; for each of the 50 states, the District of Columbia, and 200 metropolitan areas; and for internationally comparable indicators for the United States and seven other rich countries. The international results are also presented and discussed in Hernandez, Macartney, and Blanchard (2009).

2. Results in the brief are for children age 0 to 8 , unless indicated otherwise. Also, unless stated otherwise, data in this brief are taken from the Integrated Public Use Microdata Series datasets data drawn from the 2007 and 2008 American Community Surveys. An immigrant or foreignborn person is someone born outside the United States and its territories. People born in the United States, Puerto Rico, and other territories, or born abroad to U.S. citizen parents, are native born. Children with immigrant parents have at least one foreign-born parent.

3. Two-thirds of immigrants live in the six traditional destination states. In 22 states, the foreign-born populations grew more quickly between 1990 and 2000 than they did in the six traditional destination states. These states are Alabama, Arizona, Arkansas, Colorado, Delaware, Georgia, Idaho, Indiana, Iowa, Kansas, Kentucky, Minnesota, Mississippi, Nebraska, Nevada, North Carolina, Oklahoma, Oregon, South Carolina, Tennessee, Utah, and Washington (Capps et al. 2007; Fortuny, Capps, and Passel 2007).

4. English language learners report that they speak a language other than English at home and speak English well, not well, or not at all. English-fluent persons speak English exclusively or very well. Those who speak another language at home and speak English very well are classified here as bilingual and English fluent. English fluency is not recorded for children under age 5 .

5. In mixed-status families, at least one child is a U.S. citizen and neither parent is a citizen. Noncitizens include legal immigrants, such as legal permanent residents and refugees, and unauthorized immigrants. The U.S.

Census data do not identify the legal immigrant status of respondents. In 2008, 4 million children born in the United States had unauthorized immigrant parents (Passel and Cohn 2009).

6. Parental education is defined as the highest attainment of the mother and/or father.

7. Poor is family income below the federal poverty level, and low income is family income below twice the federal poverty level. Poverty levels are adjusted for family size. In 2007 , the federal poverty level was $\$ 21,203$ for a family of four, slightly higher for larger families, and lower for smaller families. Twice the federal poverty level in 2007 was $\$ 42,406$ for a family of four.

\section{References}

Capps, Randy, Everett Henderson, John D. Kasarda, James H. Johnson Jr., Stephen J. Appold, Derrek L. Croney, Donald J. Hernandez, and Michael Fix. 2007. A Profile of Immigrants in Arkansas: Executive Summary. Washington, DC: The Urban Institute.

Fortuny, Karina, Randy Capps, and Jeffrey S. Passel. 2007. "The Characteristics of Unauthorized Immigrants in California, Los Angeles County, and the United States.” Washington, DC: The Urban Institute.

Hernandez, Donald J., Nancy A. Denton, and Suzanne E. Macartney. 2008. "Children in Immigrant Families: Looking to America's Future." Social Policy Report 22(3): 1-24.

. Forthcoming. "Early Childhood Education Programs: Accounting for Low Enrollment in Newcomer and Native Families." In The New Dimensions of Diversity: The Children of Immigrants in North America and Western Europe, edited by Richard Alba and Mary A. Waters. New York: NYU Press.

Hernandez, Donald J., Suzanne Macartney, and Victoria L. Blanchard. 2009. Children in Immigrant Families in Eight Affluent Countries: Their Family, National, and International Context. Florence, Italy: UNICEF Innocenti Research Centre.

Hernandez, Donald J., Suzanne Macartney, and Nancy A. Denton. 2010. "Young English Language Learners: A Demographic Portrait." In Young English Language Learners: Current Research and Emerging Directions for Practice and Policy, edited by Eugene E. Garcia and Ellen Frede. New York: Teachers College Press.

\section{About the Authors}

Karina Fortuny is a research associate in the Urban Institute's Center on Labor, Human Services, and Population Studies with a main focus on the diverse U.S. immigrant population. She has recently developed an online data tool with comprehensive information on the characteristics of children of immigrants nationwide and for individual states and the District of Columbia.

Donald J. Hernandez serves as a professor in the department of sociology, Hunter College and the Graduate Center, City University of New York (CUNY), and as senior advisor to the Foundation for Child Development.

Ajay Chaudry is a senior fellow at the Urban Institute and directs the Institute's Immigration Studies Program. 
APPENDIX TABLE 1. Number and Share of Children Age 0-8 with Immigrant Parents by State, 1990-2008

\begin{tabular}{|c|c|c|c|c|c|c|c|}
\hline \multirow[b]{2}{*}{ State } & \multicolumn{3}{|c|}{1990} & \multicolumn{3}{|c|}{ 2007-08 } & \multirow[b]{2}{*}{$\begin{array}{l}\text { Percent } \\
\text { growth }\end{array}$} \\
\hline & Number & $\begin{array}{c}\text { Rank } \\
\text { (by number) }\end{array}$ & $\begin{array}{l}\% \text { of U.S. } \\
\text { Children }\end{array}$ & Number & $\begin{array}{c}\text { Rank } \\
\text { (by number) }\end{array}$ & $\begin{array}{l}\% \text { of U.S. } \\
\text { Children }\end{array}$ & \\
\hline Alabama & 11,000 & 33 & 2 & 36,000 & 33 & 7 & 241 \\
\hline Alaska & 8,000 & 39 & 8 & 9,000 & 44 & 11 & 20 \\
\hline Arizona & 74,000 & 8 & 15 & 278,000 & 7 & 32 & 277 \\
\hline Arkansas & 6,000 & 42 & 2 & 37,000 & 32 & 11 & 496 \\
\hline California & $1,531,000$ & 1 & 38 & $2,254,000$ & 1 & 50 & 47 \\
\hline Colorado & 38,000 & 17 & 9 & 139,000 & 14 & 23 & 265 \\
\hline Connecticut & 48,000 & 14 & 12 & 90,000 & 21 & 24 & 87 \\
\hline Delaware & 5,000 & 45 & 6 & 20,000 & 40 & 20 & 328 \\
\hline $\begin{array}{l}\text { District of } \\
\text { Columbia }\end{array}$ & 7,000 & 40 & 13 & 14,000 & 41 & 24 & 88 \\
\hline Florida & 282,000 & 4 & 19 & 599,000 & 4 & 31 & 112 \\
\hline Georgia & 42,000 & 16 & 5 & 242,000 & 8 & 19 & 477 \\
\hline Hawaii & 32,000 & 18 & 22 & 39,000 & 31 & 28 & 21 \\
\hline Idaho & 9,000 & 35 & 6 & 27,000 & 37 & 13 & 210 \\
\hline Illinois & 209,000 & 5 & 14 & 417,000 & 5 & 27 & 100 \\
\hline Indiana & 20,000 & 27 & 3 & 69,000 & 24 & 9 & 243 \\
\hline lowa & 8,000 & 37 & 2 & 34,000 & 34 & 10 & 308 \\
\hline Kansas & 19,000 & 30 & 5 & 48,000 & 30 & 14 & 160 \\
\hline Kentucky & 8,000 & 38 & 2 & 27,000 & 38 & 5 & 234 \\
\hline Louisiana & 20,000 & 25 & 3 & 27,000 & 39 & 5 & 30 \\
\hline Maine & 7,000 & 41 & 4 & 9,000 & 45 & 7 & 30 \\
\hline Maryland & 63,000 & 12 & 10 & 155,000 & 13 & 24 & 145 \\
\hline Massachusetts & 105,000 & 7 & 15 & 175,000 & 11 & 26 & 67 \\
\hline Michigan & 66,000 & 11 & 5 & 127,000 & 17 & 11 & 93 \\
\hline Minnesota & 29,000 & 19 & 5 & 97,000 & 18 & 16 & 236 \\
\hline Mississippi & 5,000 & 44 & 2 & 12,000 & 43 & 3 & 115 \\
\hline Missouri & 18,000 & 31 & 3 & 49,000 & 29 & 7 & 172 \\
\hline Montana & 3,000 & 48 & 2 & 5,000 & 46 & 4 & 85 \\
\hline Nebraska & 6,000 & 43 & 3 & 29,000 & 35 & 13 & 371 \\
\hline Nevada & 24,000 & 24 & 15 & 128,000 & 16 & 38 & 441 \\
\hline New Hampshire & 8,000 & 36 & 6 & 13,000 & 42 & 10 & 60 \\
\hline New Jersey & 174,000 & 6 & 19 & 339,000 & 6 & 34 & 95 \\
\hline New Mexico & 26,000 & 23 & 11 & 49,000 & 27 & 20 & 93 \\
\hline New York & 481,000 & 2 & 23 & 732,000 & 3 & 35 & 52 \\
\hline North Carolina & 28,000 & 21 & 4 & 193,000 & 9 & 17 & 578 \\
\hline North Dakota & 2,000 & 51 & 2 & 2,000 & 51 & 4 & 32 \\
\hline Ohio & 43,000 & 15 & 3 & 90,000 & 20 & 7 & 110 \\
\hline Oklahoma & 20,000 & 28 & 5 & 53,000 & 26 & 12 & 165 \\
\hline Oregon & 29,000 & 20 & 8 & 96,000 & 19 & 22 & 232 \\
\hline Pennsylvania & 62,000 & 13 & 4 & 137,000 & 15 & 10 & 121 \\
\hline Rhode Island & 20,000 & 26 & 17 & 28,000 & 36 & 26 & 38 \\
\hline South Carolina & 10,000 & 34 & 2 & 49,000 & 28 & 10 & 366 \\
\hline South Dakota & 2,000 & 50 & 2 & 4,000 & 48 & 4 & 104 \\
\hline Tennessee & 14,000 & 32 & 2 & 73,000 & 23 & 10 & 438 \\
\hline Texas & 473,000 & 3 & 19 & $1,115,000$ & 2 & 33 & 136 \\
\hline Utah & 20,000 & 29 & 6 & 76,000 & 22 & 17 & 289 \\
\hline Vermont & 3,000 & 47 & 4 & 4,000 & 47 & 7 & 27 \\
\hline Virginia & 66,000 & 10 & 9 & 171,000 & 12 & 19 & 158 \\
\hline Washington & 74,000 & 9 & 11 & 191,000 & 10 & 26 & 159 \\
\hline West Virginia & 3,000 & 46 & 2 & 4,000 & 49 & 2 & 5 \\
\hline Wisconsin & 27,000 & 22 & 4 & 62,000 & 25 & 10 & 129 \\
\hline Wyoming & 2,000 & 49 & 3 & 3,000 & 50 & 4 & 29 \\
\hline United States & $4,290,000$ & & 13 & $8,676,000$ & & 24 & 102 \\
\hline Big six states & $3,150,000$ & & 25 & $5,456,000$ & & 38 & 73 \\
\hline $\begin{array}{l}\text { New-growth } \\
\text { states }\end{array}$ & 498,000 & & 5 & $1,954,000$ & & 16 & 292 \\
\hline Other & 642,000 & & 7 & $1,265,000$ & & 13 & 97 \\
\hline
\end{tabular}

Source: Urban Institute tabulations from the IPUMS datasets drawn from the 1990 U.S. Census of Population and Housing, 5 percent sample, and the 2007 and 2008 American Community Surveys.

Notes: The big six states are those with the largest immigrant populations: California, New York, Texas, Florida, Illinois, and New Jersey. The 22 new-growth states are Alabama, Arkansas, Arizona, Colorado, Delaware, Georgia, Iowa, Idaho, Indiana, Kansas, Kentucky, Minnesota, Mississippi, North Carolina, Nebraska, Nevada, Oklahoma, Oregon, South Carolina, Tennessee, Utah, and Washington. Numbers are rounded to the nearest thousand. Numbers may not sum to totals because of rounding. Percentages are based on unrounded numbers. 
APPENDIX TABLE 2. Children Age 0-8 with Immigrant Parents by Parents' Country of Origin, 2008

\begin{tabular}{|c|c|c|c|c|}
\hline Region & Country & Number & Rank & $\begin{array}{l}\text { Share of children } \\
\text { of immigrants }\end{array}$ \\
\hline Mexico & $\begin{array}{l}\text { Mexico } \\
\text { Subtotal }\end{array}$ & $\begin{array}{l}3,723,000 \\
3,723,000\end{array}$ & 1 & $\begin{array}{l}43 \% \\
43 \%\end{array}$ \\
\hline Central America & $\begin{array}{l}\text { Belize/British Honduras } \\
\text { Costa Rica } \\
\text { El Salvador } \\
\text { Guatemala } \\
\text { Honduras } \\
\text { Nicaragua } \\
\text { Panama } \\
\text { Subtotal }\end{array}$ & $\begin{array}{r}10,000 \\
17,000 \\
286,000 \\
166,000 \\
114,000 \\
46,000 \\
19,000 \\
657,000\end{array}$ & $\begin{array}{r}80 \\
63 \\
4 \\
8 \\
12 \\
31 \\
57\end{array}$ & $\begin{array}{l}0 \% \\
0 \% \\
3 \% \\
2 \% \\
1 \% \\
1 \% \\
0 \% \\
8 \%\end{array}$ \\
\hline Caribbean & $\begin{array}{l}\text { Antigua-Barbuda } \\
\text { Bahamas } \\
\text { Barbados } \\
\text { Cuba } \\
\text { Dominica } \\
\text { Dominican Republic } \\
\text { Grenada } \\
\text { Haiti } \\
\text { Jamaica } \\
\text { St. Kitts-Nevis } \\
\text { St. Lucia } \\
\text { St. Vincent } \\
\text { Trinidad and Tobago } \\
\text { Caribbean, not specified } \\
\text { Subtotal }\end{array}$ & $\begin{array}{c}4,000^{\mathrm{a}} \\
8,000 \\
8,000 \\
102,000 \\
9,000 \\
174,000 \\
5,000^{\mathrm{a}} \\
124,000 \\
110,000 \\
2,000^{\mathrm{a}} \\
5,000^{\mathrm{a}} \\
4,000^{\mathrm{a}} \\
44,000 \\
10,000 \\
607,000\end{array}$ & $\begin{array}{r}125 \\
91 \\
93 \\
15 \\
89 \\
7 \\
111 \\
11 \\
13 \\
133 \\
113 \\
125 \\
34 \\
84\end{array}$ & $\begin{array}{l}0 \% \\
0 \% \\
0 \% \\
0 \% \\
1 \% \\
0 \% \\
2 \% \\
0 \% \\
0 \% \\
1 \% \\
1 \% \\
0 \% \\
0 \% \\
0 \% \\
1 \% \\
0 \% \\
7 \%\end{array}$ \\
\hline South America & $\begin{array}{l}\text { Argentina } \\
\text { Bolivia } \\
\text { Brazil } \\
\text { Chile } \\
\text { Colombia } \\
\text { Ecuador } \\
\text { Guyana/British Guiana } \\
\text { Paraguay } \\
\text { Peru } \\
\text { Uruguay } \\
\text { Venezuela } \\
\text { South America, not specified } \\
\text { Subtotal }\end{array}$ & $\begin{array}{r}35,000 \\
16,000 \\
67,000 \\
17,000 \\
104,000 \\
86,000 \\
43,000 \\
3,000^{\mathrm{a}} \\
79,000 \\
10,000 \\
40,000 \\
8,000 \\
\mathbf{5 0 8 , 0 0 0}\end{array}$ & $\begin{array}{r}40 \\
64 \\
21 \\
62 \\
14 \\
16 \\
35 \\
132 \\
17 \\
83 \\
36 \\
92\end{array}$ & $\begin{array}{l}0 \% \\
0 \% \\
1 \% \\
0 \% \\
1 \% \\
1 \% \\
0 \% \\
0 \% \\
1 \% \\
0 \% \\
0 \% \\
0 \% \\
6 \%\end{array}$ \\
\hline East Asia \& Pacific & $\begin{array}{l}\text { China } \\
\text { Fiji } \\
\text { Hong Kong } \\
\text { Indonesia } \\
\text { Japan } \\
\text { Korea } \\
\text { Malaysia } \\
\text { Micronesia } \\
\text { Philippines } \\
\text { Samoa } \\
\text { Singapore } \\
\text { Taiwan } \\
\text { Tonga } \\
\text { East Asia \& Pacific, not specified } \\
\text { Subtotal }\end{array}$ & $\begin{array}{c}179,000 \\
6,000^{\mathrm{a}} \\
25,000 \\
13,000 \\
63,000 \\
149,000 \\
12,000 \\
5,000^{\mathrm{a}} \\
289,000 \\
5,000 \\
4,000^{\mathrm{a}} \\
47,000 \\
5,000^{\mathrm{a}} \\
2,000^{\mathrm{a}} \\
804,000\end{array}$ & $\begin{array}{r}6 \\
102 \\
50 \\
73 \\
25 \\
9 \\
75 \\
106 \\
3 \\
109 \\
122 \\
30 \\
112 \\
134\end{array}$ & $\begin{array}{l}2 \% \\
0 \% \\
0 \% \\
0 \% \\
1 \% \\
2 \% \\
0 \% \\
0 \% \\
3 \% \\
0 \% \\
0 \% \\
1 \% \\
0 \% \\
0 \% \\
9 \%\end{array}$ \\
\hline Southeast Asia & $\begin{array}{l}\text { Burma (Myanmar) } \\
\text { Cambodia } \\
\text { Laos } \\
\text { Thailand } \\
\text { Vietnam } \\
\text { Subtotal }\end{array}$ & $\begin{array}{r}10,000 \\
31,000 \\
53,000 \\
39,000 \\
225,000 \\
358,000\end{array}$ & $\begin{array}{r}85 \\
43 \\
27 \\
37 \\
5\end{array}$ & $\begin{array}{l}0 \% \\
0 \% \\
1 \% \\
0 \% \\
3 \% \\
4 \%\end{array}$ \\
\hline
\end{tabular}


APPENDIX TABLE 2. Children Age 0-8 with Immigrant Parents by Parents' Country of Origin, 2008 (Continued)

\begin{tabular}{|c|c|c|c|c|}
\hline Region & Country & Number & Rank & $\begin{array}{c}\text { Share of children } \\
\text { of immigrants }\end{array}$ \\
\hline \multirow[t]{6}{*}{ South Central Asia } & India & 319,000 & 2 & $4 \%$ \\
\hline & Bangladesh & 37,000 & 39 & $0 \%$ \\
\hline & Pakistan & 74,000 & 18 & $1 \%$ \\
\hline & Sri Lanka & 6,000 & 105 & $0 \%$ \\
\hline & Nepal & 6,000 & 101 & $0 \%$ \\
\hline & Subtotal & 441,000 & & $5 \%$ \\
\hline \multirow[t]{13}{*}{ Middle East } & Afghanistan & 16,000 & 66 & $0 \%$ \\
\hline & Iran & 44,000 & 33 & $1 \%$ \\
\hline & Iraq & 24,000 & 52 & $0 \%$ \\
\hline & |srael/Palestine & 50,000 & 28 & $1 \%$ \\
\hline & Jordan & 25,000 & 49 & $0 \%$ \\
\hline & Kuwait & 13,000 & 74 & $0 \%$ \\
\hline & Lebanon & 38,000 & 38 & $0 \%$ \\
\hline & Saudi Arabia & $5,000^{\mathrm{a}}$ & 114 & $0 \%$ \\
\hline & Syria & 15,000 & 69 & $0 \%$ \\
\hline & Turkey & 20,000 & 54 & $0 \%$ \\
\hline & Yemen Arab Republic (North) & 16,000 & 67 & $0 \%$ \\
\hline & Middle East, not specified & 18,000 & 60 & $0 \%$ \\
\hline & Subtotal & 283,000 & & $3 \%$ \\
\hline \multirow[t]{21}{*}{ Africa } & Algeria & $3,000^{\mathrm{a}}$ & 131 & $0 \%$ \\
\hline & Cameroon & 6,000 & 99 & $0 \%$ \\
\hline & Egypt/United Arab Rep. & 27,000 & 47 & $0 \%$ \\
\hline & Eritrea & $6,000^{\mathrm{a}}$ & 97 & $0 \%$ \\
\hline & Ethiopia & 27,000 & 48 & $0 \%$ \\
\hline & Ghana & 24,000 & 51 & $0 \%$ \\
\hline & Guinea & $4,000^{a}$ & 116 & $0 \%$ \\
\hline & Kenya & 16,000 & 65 & $0 \%$ \\
\hline & Liberia & 16,000 & 68 & $0 \%$ \\
\hline & Morocco & 19,000 & 56 & $0 \%$ \\
\hline & Nigeria & 62,000 & 26 & $1 \%$ \\
\hline & Senegal & $6,000^{\mathrm{a}}$ & 100 & $0 \%$ \\
\hline & Sierra Leone & 9,000 & 88 & $0 \%$ \\
\hline & Somalia & 31,000 & 42 & $0 \%$ \\
\hline & South Africa (Union of) & 19,000 & 58 & $0 \%$ \\
\hline & Sudan & 12,000 & 76 & $0 \%$ \\
\hline & Tanzania & $4,000^{\mathrm{a}}$ & 119 & $0 \%$ \\
\hline & Uganda & $2,000^{a}$ & 135 & $0 \%$ \\
\hline & Zimbabwe & $4,000^{\mathrm{a}}$ & 120 & $0 \%$ \\
\hline & Africa, not specified & 67,000 & 22 & $1 \%$ \\
\hline & Subtotal & 366,000 & & $4 \%$ \\
\hline Central and & Albania & 15,000 & 71 & $0 \%$ \\
\hline \multirow{23}{*}{ Eastern Europe } & Armenia & 12,000 & 78 & $0 \%$ \\
\hline & Azerbaijan & $2,000^{\mathrm{a}}$ & 137 & $0 \%$ \\
\hline & Bosnia & 19,000 & 55 & $0 \%$ \\
\hline & Bulgaria & 9,000 & 90 & $0 \%$ \\
\hline & Byelorussia & 7,000 & 96 & $0 \%$ \\
\hline & Croatia & $4,000^{a}$ & 118 & $0 \%$ \\
\hline & Czech Republic & 6,000 & 103 & $0 \%$ \\
\hline & Estonia & $1,000^{\mathrm{a}}$ & 139 & $0 \%$ \\
\hline & Georgia & $2,000^{\mathrm{a}}$ & 136 & $0 \%$ \\
\hline & Hungary & 10,000 & 82 & $0 \%$ \\
\hline & Kazakhstan & $5,000^{\mathrm{a}}$ & 110 & $0 \%$ \\
\hline & Latvia & $4,000^{\mathrm{a}}$ & 117 & $0 \%$ \\
\hline & Lithuania & $4,000^{a}$ & 115 & $0 \%$ \\
\hline & Macedonia & $4,000^{a}$ & 128 & $0 \%$ \\
\hline & Moldavia & $5,000^{\mathrm{a}}$ & 108 & $0 \%$ \\
\hline & Other USSR/Russia & 66,000 & 23 & $1 \%$ \\
\hline & Poland & 68,000 & 20 & $1 \%$ \\
\hline & Romania & 28,000 & 46 & $0 \%$ \\
\hline & Slovakia & $4,000^{a}$ & 127 & $0 \%$ \\
\hline & Ukraine & 49,000 & 29 & $1 \%$ \\
\hline & Uzbekistan & 9,000 & 87 & $0 \%$ \\
\hline & Yugoslavia & 17,000 & 61 & $0 \%$ \\
\hline & Subtotal & 349,000 & & $4 \%$ \\
\hline
\end{tabular}


APPENDIX TABLE 2. Children Age 0-8 with Immigrant Parents by Parents' Country of Origin, 2008 (Continued)

\begin{tabular}{|c|c|c|c|c|}
\hline Region & Country & Number & Rank & $\begin{array}{l}\text { Share of children } \\
\text { of immigrants }\end{array}$ \\
\hline Western Europe, & Canada & 148,000 & 10 & $2 \%$ \\
\hline Canada, and & Australia & 19,000 & 59 & $0 \%$ \\
\hline \multirow[t]{26}{*}{ Australia } & Austria & $4,000^{a}$ & 123 & $0 \%$ \\
\hline & Azores & $3,000^{a}$ & 130 & $0 \%$ \\
\hline & Belgium & 6,000 & 104 & $0 \%$ \\
\hline & Bermuda & $1,000^{\mathrm{a}}$ & 140 & $0 \%$ \\
\hline & Cape Verde & 7,000 & 95 & $0 \%$ \\
\hline & Denmark & 5,000 & 107 & $0 \%$ \\
\hline & England & 70,000 & 19 & $1 \%$ \\
\hline & Finland & $3,000^{\mathrm{a}}$ & 129 & $0 \%$ \\
\hline & France & 29,000 & 44 & $0 \%$ \\
\hline & Germany & 64,000 & 24 & $1 \%$ \\
\hline & Greece & 12,000 & 77 & $0 \%$ \\
\hline & Iceland & $1,000^{\mathrm{a}}$ & 138 & $0 \%$ \\
\hline & Ireland & 29,000 & 45 & $0 \%$ \\
\hline & Italy & 32,000 & 41 & $0 \%$ \\
\hline & Netherlands & 13,000 & 72 & $0 \%$ \\
\hline & New Zealand & 7,000 & 94 & $0 \%$ \\
\hline & Northern Ireland & $4,000^{\mathrm{a}}$ & 124 & $0 \%$ \\
\hline & Norway & $4,000^{a}$ & 121 & $0 \%$ \\
\hline & Portugal & 20,000 & 53 & $0 \%$ \\
\hline & Scotland & 9,000 & 86 & $0 \%$ \\
\hline & Spain & 15,000 & 70 & $0 \%$ \\
\hline & Sweden & 10,000 & 81 & $0 \%$ \\
\hline & Switzerland & 6,000 & 98 & $0 \%$ \\
\hline & United Kingdom, not specified & 45,000 & 32 & $1 \%$ \\
\hline & Western Europe, not specified & 11,000 & 79 & $0 \%$ \\
\hline & Subtotal & 579,000 & & $7 \%$ \\
\hline Total & & $8,676,000$ & & $100 \%$ \\
\hline
\end{tabular}

Source: Urban Institute estimates from the IPUMS datasets drawn from the 2007 and 2008 American Community Surveys.

Notes: Numbers are rounded to the nearest thousand. Numbers may not sum to totals because of rounding. Percentages are based on unrounded numbers.

a. Estimates are based on a small sample size (fewer than 100 observations). 


\section{THE URBAN INSTITUTE}

2100 M Street, NW

Washington, DC 20037

Copyright @ 2010

Phone: 202-833-7200

Fax: 202-467-5775

Web: http://www.urban.org
To order additional printed copies of this publication, call 202-261-5687 or visit the UI online bookstore, http://www.uipress.org.
The children of immigrants research brief series provides timely information on children of immigrants, identifies important national and state trends and policy developments, and summarizes relevant research findings to help inform the public policy debate.
This brief was prepared with generous funding from the Foundation for Child Development and the Annie E. Casey Foundation.

The views expressed are those of the authors and do not necessarily reflect those of the Urban Institute, its board, its sponsors, or other authors in this series. Permission is granted for reproduction of this document, with attribution to the Urban Institute. 